\title{
HUMANITARIAN PROTECTIONS OF PRISONERS OF WAR
}

\section{Prisoners of War in International Criminal LaW}

There have, until recently, been very few regulations governing the treatment of prisoners of war under the system of international criminal law. Attempts at such regulations have been very weak and have not been binding internationally. Most of the earlier rules in international criminal law dealing with armed conflicts are without any especially effective regulations relating to the status of prisoners of war. These rules were formulated during the second half of the nineteenth century and did not give prisoners of war any special legal protection. ${ }^{1}$

The events of the First and the Second World Wars and especially the mass killings of Jewish prisoners in the Second World War were strong proof of a lack of regulations under the international legal system. A single agreement was however in force. This was the 1929 Convention concerning the Treatment of Prisoners of War and was applicable between the major Western states. This Convention was also the development of the Hague Regulations of 1899 and 1907 governing the law of war or armed conflicts, but none of these agreements could provide the necessary support for the consolidation of the position of prisoners of war. This was for several reasons; Firstly, these agreements had mostly regional rather than international effects. Secondly, the legal scope of applicability of the 1899 and 1907 regulations was very narrow and indeed impractical from a political aspect. Thirdly, at the time of the drafting of the Regulations and the 1929 Convention many states of the world were under colonial domination and were not therefore free to express their own legal consent. Thus, these agreements were formulated in accordance with the will of colonial and powerful states and their allies. Fourthly, the legal framework of the system of international criminal law was not recognised as it is recognised today and therefore the characterization of the law of armed conflicts was, more or less, a matter of formality, not of

\footnotetext{
${ }^{1}$ Malekian, International Criminal Law, vol. I, p. 100 seq.
} 
implementation and enforcement. The International Military Tribunals in Nuremberg and Tokyo implemented the system of international criminal law to some extent but only according to the will and interests of the victorious states.

The third Geneva Convention Relative to the Treatment of Prisoners of War, 1949, has, however, converted the unstable and irregular situation of prisoners of war and a large number of states including Islamic nations are parties to this Convention, which basically aims at harmonizing and humanizing the status of prisoners of war. The Convention contains a number of humanitarian provisions in order to eliminate acts which may, in one way or another, cause various forms of harm to prisoners of war. Accordingly, parties have undertaken to take the necessary measures for the implementation of the provisions of the Convention. In particular the 1949 Convention, among many other provisions governing the protection of prisoners of war states that its provisions must be respected fully by the conflicting parties and any unlawful acts against a prisoner by the detaining power causing his death or endangering the health of the prisoner are not only prohibited, but can also be regarded as a serious violation of the provisions of the Convention. The Convention also protects prisoners from any act against their dignity, exercise of religious duties, right to food or any other necessity, medical treatment, personal honour, insults and public curiosity.

Today, the provisions of the convention have the effect of customary international criminal law, which means that they must be respected by all means by the conflicting parties in an armed conflict. The provisions of the convention are binding upon all those who are involved in armed conflicts regardless of whether or not they are parties to the convention. Respect for the provisions of the convention is so important that it should not be denied by any state. This is why we call it jus cogens principle. The convention is also strengthened by the provisions of the 1977 Geneva Protocol I, Relating to the Protection of Victims of International Armed Conflicts and the 1977 Geneva Protocol II, Relating to the Protection of Victims of Non-International Armed Conflicts, both of which are Additional to the Geneva Conventions of 12 August 1949. Despite this, the provisions of the 1949 Convention Relative to the Treatment of Prisoners of War and the additional Protocols have been violated in most national and international armed conflicts such as Vietnam, Cambodia, Mai Lay and Yugoslavia. They were more seriously violated in the United States and the United Kingdom war in Iraq. The military authorities of both permanent members of the United Nations committed serious 
and grave violations of the international humanitarian law of armed conflicts in Iraq without any international response for their prosecution and punishment. Clear examples of these crimes were in Abu Ghraib Prison against the prisoners. Their physical and psychological integrities were necked, raped, humiliated, tortured, degraded, insulted, abused, offended and seriously harmed and injured by the legal authorities under the direct or indirect supervisions of the superiors.

\section{Prisoners of WAR IN}

Islamic InTERnational Criminal LaW

\subsection{Definition}

In Islamic international criminal law prisoners of war are those who have, in one way or another, been captured during a state of hostility in actual armed conflicts between the conflicting parties and are consequently considered enemy combatants. ${ }^{2}$

In the early practice of Islamic international criminal law, prisoners of war could be enslaved due to the prevailing practice of the Middle Ages and in accordance with the incorrect interpretation of one of the verses of Qur'ān to save individuals from further killing. ${ }^{3}$ The verse reads that 'So when you encounter the unbelievers in a battle, smite at their necks until when you have slaughtered them and consequently have overcome them, then you imprison them, and afterwards either set them free as a favour or taking some ransom until they lay down their arms, this is a just Law of God for war mongers; and if God had pleased, He would have taken revenge from them Himself, but (He lets you fight) that He may try some of you by the others; and those who are slain in the Way of God, so He never let their deeds to go in vain., ${ }^{4}$ For this reason one cannot deny that Islamic international criminal law did not permit prisoners of war to be reduced to the status of slavery because of the circumstances of the ancient time and misunderstanding of the law.

In certain situations the practice was however different, as prisoners were divided among those who had conducted the war. Prisoners of war

2 According to one writer, 'The prisoners of war are the enemy combatants who, in a legitimate war declared by a Muslim sovereign, were made prisoners by Muslims.' AlGhunaimi, The Muslim Conception of International Law and Western Approach, p. 148.

3 The Qur'àn, 47:4.

${ }^{4}$ The Qur'àn, 47:4. 
could therefore be enslaved in situations considered proportionate to the hostile activities of the enemy state. In connection with the above verse and the position of the prisoners of war it is rightly asserted that the Islamic state had "the choice only between two alternatives; either to set free the prisoners of war gratuitously or to claim ransom. The verse unequivocally does not entitle the Muslims to enslave their prisoners of war since it does not contemplate such right. Moreover, it-a contrarioforbids enslavement." ${ }^{\text {It }}$ should be further stated that "the permission of enslaving the prisoners of war is given as a measure of retaliation and not as a right $a b$ initio. Therefore, the Muslims are not entitled to enslave their prisoners of war whenever they like but only when their enemy enslaves the Muslim prisoners of war. In other words Islamic law of war does not contain enslavement as one of its tenets but as a sanction that could be inflicted on a basis of reciprocity." It must therefore be emphasised that the Qur'ann does not support enslavement of prisoners of war and although it was sometimes practised during the early days of Islamic law (close to fourteen hundred years ago) the practice has gradually been abolished.

The Prophet of Islam prevented this practice as much as was possible and actively encouraged its abolition. ${ }^{7}$ This means that the relevant verse of the Qur'än was practised by the Prophet and the second source of Islamic international criminal law i.e. Sunnah was strongly interpreted as a means of promoting its abolition. Thus, it is certainly incorrect to state that in Islamic law enslavement of prisoners was an absolute right of the military commanders or superiors and that there was no tendency towards its abolition. This is irrespective of the fact that there are a number of cases documenting the enslavement of prisoners of war in the early practice of the Muslim states. In any event, enslavement did not constitute a right but an amnesty to mitigate further killings and family unity suffering. Because of the development of international relations and according to the modern interpretation of Islamic law, enslavement is considered a grave violation of the Islamic international humanitarian law of armed conflicts. ${ }^{8}$

\footnotetext{
${ }^{5}$ Emphasis added. Al-Ghunaimi, The Muslim Conception of International Law and Western Approach, p. 190.

${ }^{6}$ Id., pp. 190-191.

7 See chapter fourteen.

8 That is why international conventions prohibiting slavery are signed by states with Muslim populations. For data see Bassiouni, The Islamic Criminal Justice System, pp. 4853 .
} 


\subsection{Protections}

Islamic international criminal law lays down a number of humanitarian principles in order to protect those who have been captured as prisoners during a regional or an international armed conflict. These principles may be regarded as the earliest and most consolidated principles of international humanitarian law of armed conflicts which have been achieved in the history of civilisation. They provide certain basic guarantees for prisoners which have only recently been codified in the modern legislations of the system of international criminal law. ${ }^{9}$

According to Islamic international criminal law the following principles must be fulfilled with respect to prisoners who have been captured during an armed conflict. ${ }^{10}$ These are:

1. Prisoners should not be held responsible for the cause of hostilities between the conflicting parties.

2. Prisoners who have acted in accordance with the law of war during an armed conflict should not be held responsible for whatsoever damages caused to the conflicting parties.

3. Food and any other necessities such as clothes must be provided for all prisoners and they should not be charged to that effect.

4. A conflicting party who holds prisoners should provide appropriate shelter for their protection.

5. The dignity and integrity of prisoners should not be disregarded.

6. Any cause of human suffering must be avoided. This includes torture and the humiliation of prisoners.

7. Superiors must be equally respected.

8. The cultural attitudes of prisoners must fully be respected.

9. Females' position should especially be respected.

10. No person should be raped.

11. Females, minors, disable persons and families must be given special respect because of their particular status.

12. Family unity should be respected.

\footnotetext{
${ }^{9}$ Some important traditions may be useful to mention here. i) A prisoner could generally be released upon a ransom; ii) A non-Arab origin prisoner could be released only for half of that ransom in (i); iii) A prisoner could be released on the grounds of teaching knowledge to others; iv) Poverty of a prisoner could be a basic reason for one's immediate unconditional release; $v$ ) Transportation of prisoners should be carried out on the best possible facilities. Hamidullah, The Battlefields of the Prophet Muhammad, p. 17.

${ }^{10}$ Hamidullah, The Muslim Conduct of State, pp. 205-208.
} 
13. Mothers should not be separated from their children.

14. Close relatives should not be separated from one another.

15. In all procedures prisoners should be treated fairly by the conflicting parties.

16. Communications by letter or other forms of this type should be handed over to the relevant enemy authorities.

17. Prisoners who suffer from special discomfiture or a special condition should as far as possible, be given help to that effect.

18. Sick and wounded must, where possible, be given medical services.

19. Compulsory work should not be imposed on prisoners.

20. Prisoners should not be forced to fight against their own will.

21. Capital punishment should not be carried out on prisoners of war. ${ }^{11}$

22. Any forms of retaliation or revenge on prisoners are prohibited.

23. Prisoners who have escaped to their own country and are again captured during an armed conflict should not be punished for a previous escape(s).

24. Prisoners who violate discipline may be punished accordingly.

25. A prisoner of war who is accused of having committed activities beyond the rights, rules and regulations of belligerency may be brought before a tribunal for the purpose of prosecution and if his guilt is proved without any reasonable doubt, he may be punished.

26. The above provisions are a duty of the conflicting parties and therefore parties should not expect prisoners to be grateful for the fulfilment of such a duty.

Islamic law also recognises certain duties for Islamic states to negotiate, as soon as possible, for the release of Muslim soldiers captured by enemy states. According to the main source of Islamic law, certain incomes from a Muslim state must be specified and administrated for that purpose. ${ }^{12}$ Similarly, ransom is permitted by the Qur'an for the release of prisoners of war and simultaneously recommends the generous release of prisoners of war when hostilities have ceased. ${ }^{13}$ Whenever possible, prisoners of war should also be exchanged between conflicting parties.

11 An exception to this principle is to be found in extreme situations of military necessity for the interests of a conflicting party. It has however been demonstrated that the companions of the Prophet were unanimous that the death penalty should not be carried out on prisoners of war. Id., pp. 208-209.

${ }^{12}$ The Qur'än, 9:60.

13 The Qur'ān, 47:4. See the previous sub-section. 
With all these provisions, Islamic international criminal law diminishes the risk of killing prisoners of war through acts of revenge, hostility or reprisals and harmonizes the activities of conflicting parties in order to achieve peaceful settlements of national, regional and international disputes. 